\title{
BINOMIAL LOGIT MODEL UNTUK PEMILIHAN MODA ANTARA PESAWAT UDARA, KERETA API EKSEKUTIF DAN KERETA API EKSPRES
}

\section{BINOMIAL LOGIT MODEL FOR SELECTING MODA BETWEEN AIRCRAFT, EXECUTIVE TRAIN AND EXPRESS TRAIN}

\author{
Djoko Prijo Utomo dan Mulyadi Sinung Harjono \\ Pusat Teknologi Sistem dan PrasaranaTransportasi \\ Deputi Teknologi Industri Rancang Bangun dan Rekayasa - BPPT \\ Gedung Teknologi 2 BPPT Lantai 3, Kawasan PUSPIPTEK, Tangerang Selatan 15314 \\ Telp: 021-75875938; Fax. 021-75875946 \\ Email: djokoprijo@yahoo.com
}

\begin{abstract}
Abstrak
Penelitian ini dilakukan untuk mengkaji potensi pasar rencana pembangunan kereta api ekspres Jakarta - Semarang. Survei stated preference dan model logit binomial digunakan untuk mengidentifikasi kompetisi antara moda kereta api ekspres dengan pesawat udara maupun kereta api kelas eksekutif yang telah beroperasi. Atribut yang digunakan adalah travel time dan travel cost. Hasil analisis regresi untuk model utility cukup baik dengan indikator $\mathrm{R}^{2}$ sebesar 0,51 untuk penumpang pesawat udara dan 0,56 untuk penumpang kereta api kelas api eksekutif. Hasil temuan menunjukkan bahwa penumpang pesawat udara lebih sensitif terhadap perubahan waktu tempuh dibandingkan penumpang kereta api (KA) eksekutif, dan penumpang pesawat udara juga memiliki kemampuan membeli yang lebih tinggi dibandingkan penumpang KA eksekutif. Jika waktu perjalanan KA ekspres 2,8 jam (kecepatan rata-rata 155,5 km/jam), maka potensi pendapatan terbesar terjadi jika tarif Rp. 360.000,/penumpang.
\end{abstract}

Kata kunci : Kereta Api, potensi permintaan, Stated Preference, Binomial Logit Model

\begin{abstract}
This research assesses the potential market of the development planned of the Jakarta - Semarang express train. Stated preference surveys and binomial logit models were used to identify competition between the express train and the airplane or the executive class trains that have already operated. The attribute used is travel time and travel cost. The regression analysis results for the utility model are quite good with $R^{2}$ indicators of 0.51 for airplane passengers and 0.56 for executive class train passengers. The findings show that airplane passengers are more sensitive to the changes of the travel time than executive train passengers, and airplane passengers also have higher purchasing ability than the executive train passengers. If the express train travel time is 2.8 hours (average speed of $155.5 \mathrm{~km} / \mathrm{h}$ ), then the biggest potential revenue will be achieved if the tariff is Rp. 360,000, -/passenger.
\end{abstract}

Key Words : Railroad, potential demand, Stated Preference, Binomial Logit Model

Diterima (received ) : 04 Maret 2019 , Direvisi (revised ) : 22 Maret 2019,

Disetujui (accepted) : 28 Maret 2019 


\section{PENDAHULUAN}

\section{Latar Belakang}

Sistem transportasi regional khususnya di pulau Jawa memiliki peran strategis dalam mensinkronkan dan menyelaraskan kemajuan antar sektor ekonomi dan antar wilayah demi terwujudnya pertumbuhan ekonomi yang inklusif, sekaligus menjadi benteng bagi kedaulatan dan ketahanan ekonomi nasional (national economic authority and security). Permasalahan di dalam kegiatan trasportasi regional memiliki dimensi yang cukup luas, antara lain, masalah tingkat penyediaan infrastruktur baik kuantitas maupun kualitas, biaya transaksi, waktu pelayanan, operasional pelayanan di simpul-simpul transportasi, kapasitas dan jaringan pelayanan penyedia jasa transportasi, dan masih banyak aspek lainnya.

Jakarta dan Semarang adalah 2 (dua) kota besar di Indonesia dengan populasi masing-masing 9,59 juta jiwa dan 1,75 juta jiwa, serta menjadi magnet kota-kota sekitar. Hal ini ditunjukkan dari hasil Pra Studi Kelayakan Peningkatan Kecepatan Kereta Api Koridor Jakarta - Surabaya tahun 2017. Koridor Utara Jakarta - Surabaya memiliki kawasan aglomerasi yang sangat potensial, yaitu JABODETABEK, KEDUNGSEPUR dan GERBANGKERTOSUSILA. Saat ini penduduk Jabodetabek berjumlah 32,43 juta jiwa, Kedungsepur 6,37 juta jiwa dan Gerbangkertosusila 9,65 juta jiwa, sehingga secara keseluruhan mencapai $33,03 \%$ dari populasi Jawa (BPS, 2016). Potensi ekonomi ketiga wilayah tersebut mencapai 55,62\% dari PDRB seluruh Pulau Jawa (PDRB Jawa $47,27 \%$ dari PDB Nasional) ${ }^{11}$.

Keterbatasan kapasitas bandar udara dan tingginya pertumbuhan permintaan perjalanan angkutan udara perlu diantisipiasi dengan mengelola permintaan perjalanan agar pergerakan orang antar kota di Pulau Jawa dapat dilayani dengan baik. Saat ini jumlah penumpang pesawat udara lebih besar dibandingkan kereta api eksekutif, di mana penumpang pesawat udara mencapai 2,85 juta penumpang/tahun dan kereta api eksekutif 0,62 juta penumpang/tahun. Kapasitas bandara Soekarno Hatta dan Ahmad Yani relatif sangat terbatas, sehingga perlu adanya pengelolaan permintaan penumpang pesawat udara. Salah satu usaha pengelolaan permintaan perjalanan adalah dengan menyediakan system angkutan yang bersifat komplementer dan setara dengan pelayanan pesawat udara. Sistem angkutan yang relatif sama adalah dengan menyediakan pelayanan kereta api ekspres antara Jakarta - Semarang.

Untuk menentukan jenis pelayanan/kriteria kereta api baru (kereta api ekspres) yang mampu menarik penumpang secara maksimal maka perlu dilakukan survei pasar yang diharapkan dapat memberikan informasi tentang perubahan pilihan penumpang pada suatu moda terhadap alternatif kondisi pelayanan yang ditawarkan. Hasil survei pasar adalah sebuah model pemilihan moda yang dapat digunakan untuk memperkirakan probabilitas pelaku perjalanan dalam memilih moda sesuai kondisi pelayanan masing-masing moda.

\section{Maksud dan Tujuan Penelitian}

Maksud penelitian ini adalah untuk mendapatkan model pemilihan moda antara pesawat udara dan kereta api dengan kereta api ekspres koridor Jakarta-Semarang dan mengetahui besarnya probabilitas pelaku perjalanan pengguna moda pesawat udara dan kereta api eksekutif bersedia berpindah ke kereta api ekspres.

Tujuan penelitian ini adalah untuk membangun persamaan matematis model Logit Binomial yang dapat memberikan gambaran tentang kecenderungan pelaku perjalanan memilih antara moda peawat udara dengan kereta api ekspres dan kereta api eksekutif dengan kereta api ekspres.

\section{METODE PENELITIAN}

\section{Studi Pustaka}

Dalam survei preferensi, dikenal dua metode pendekatan. Pendekatan pertama adalah revealed preference (RP). Teknik revealed preference menganalisis pilihan masyarakat berdasarkan laporan yang sudah ada. Dengan menggunakan teknik statistik diidentifikasi faktor-faktor yang mempengauhi pemilihan. Teknik revealed preference memiliki kelemahan antara lain dalam hal memperkirakan respon individu terhadap suatu keadaan pelayanan yang pada saat sekarang belum ada dan bisa jadi keadaan tersebut jauh berbeda dari keadaan yang ada sekarange).

Dalam kasus-kasus seperti itu, survei stated preference digunakan sebagai gantinya, karena survei ini dapat menilai pergerakan penumpang antar wilayah bahkan ketika beberapa moda transportasi yang saat ini tidak ada dimasukkan sebagai sarana transportasi alternatif, sedangkan survei revealed preference dapat menilai pergerakan penumpang hanya dengan 
alternatif yang ada. Ada banyak penelitian semacam itu di transportasi udara dan transportasi darat, seperti Chang and Sun ${ }^{3)}$, Yulai Wan et al. ${ }^{4}$, Jiang and Zhang5), Albalate et al. ${ }^{6)}$, Xia and Zhang ${ }^{7)}{ }^{8)}$, CastilloManzano et al. ${ }^{9}$, Armstrong and Preston ${ }^{10)}$, Bilotkach et al. ${ }^{11)}$ and Jiménez and Betancor $^{12)}$.

Kelemahan pada pendekatan pertama ini dicoba diatasi dengan pendekatan kedua yang disebut teknik stated preference (SP). Teknik SP merupakan pendekatan terhadap responden untuk mengetahui respon mereka terhadap situasi yang berbeda. Pada teknik ini peneliti dapat mengontrol secara penuh faktor-faktor yang ada pada situasi yang dihipotesis. Masing-masing individu ditanya tentang responnya jika mereka dihadapkan pada situasi yang diberikan dalam keadaan yang sebenarnya (Bagaimana preferensinya terhadap pilihan yang ditawarkan).

Kebanyakan stated preference menggunakan perancangan eksperimen untuk menyusun alternatif-alternatif yang disajikan kepada responden. Rancangan ini biasanya dibuat "orthogonal", artinya kombinasi antara atribut yang disajikan bervariasi secara bebas satu sama lain. Keuntungannya adalah bahwa efek dari setiap atribut yang direspon lebih mudah diidentifikasi ${ }^{13)}$.

Suatu moda dipilih jika utilitasnya meningkat dengan beberapa alasan antara lain, pertama utilitas sendiri merupakan fungsi dari efek jaringan, makin banyak pengguna, makin bernilai layanannya, semakin tinggi utilitasnya. Kedua, utilitas meningkat seiring dengan penurunan biaya pengguna. Ketiga, adanya kemajuan teknologi yang terjadi seiring waktu dan seiring bertambahnya jumlah penggunaakan menurunkan biaya relatif ${ }^{14)}$.

Moda dipilih jika utilitasnya meningkat karena beberapa alasan, antara lain, pertama utilitas itu sendiri adalah fungsi dari efek jaringan, semakin banyak pengguna, semakin bernilai layanan, semakin tinggi utilitas. Kedua, pemanfaatan meningkat seiring dengan penurunan biaya pengguna. Ketiga, kemajuan teknologi yang terjadi seiring waktu dan dengan meningkatnya jumlah pengguna akan menurunkan biaya relatifi4).

Persamaan utilitas yang digunakan dapat dituliskan sebagai berikut:

$\begin{aligned} \log \left(\frac{P A}{1-P A}\right) & =\beta o+\beta 1(c A-C T)+\beta 2(t A-t T) \\ & =v A\end{aligned}$
Di mana:

$P A=$ probabilitas pemilihan moda baru;

$c A ; C T=$ biaya moda baru; biaya moda eksisting;

$t A ; t T=$ waktu tempuh moda baru, waktu tempuh moda eksisting; dan

$v A \quad=$ Utilitas moda baru

Model tersebut dapat diterjemahkan menjadi:

$$
\begin{aligned}
& \frac{P_{A}}{1-P_{A}}=e^{V A} \\
& P_{A}=e^{V A}-P_{A} e^{v A} \\
& P_{A}\left(1+e^{V A}\right)=e^{V A} \\
& P_{A}=\frac{e^{v A}}{1+e^{v A}}
\end{aligned}
$$

$v_{A}=\beta o+\beta 1(c A-C T)+\beta 2(t A-t T)$

Di mana setiap variabel mewakili karakteristik perjalanan. Nilai $\beta_{0}$ disebut konstanta spesifik alternatif. Kebanyakan pemodel mengatakan nilai ini mewakili karakteristik yang tidak dimasukkan dalam persamaan. Menurut Nachrowi ${ }^{15)}$, uji hipotesis berguna untuk menguji signifikansi koefisien regresi yang didapat. Artinya, koefisien regresi yang didapat secara statistik tidak sama dengan nol, karena jika sama dengan nol maka dapat dikatakan bahwa tidak cukup bukti untuk menyatakan variabel bebas mempunyai pengaruh terhadap variabel terikatnya. Untuk kepentingan tersebut, maka semua koefisien regresi harus diuji. Uji-t digunakan untuk menguji koefisien regresi secara individu. Pengujian dilakukan terhadap koefisien regresi populasi, apakah sama dengan nol, yang berarti variabel bebas tidak mempunyai pengaruh signifikan terhadap variabel terikat, atau tidak sama dengan nol, yang berarti variabel bebas mempunyai pengaruh signifikan terhadap variabel terikat.

\section{Model Pemilihan Diskrit}

Menurut Tamin ${ }^{16)}$, secara umum model pemilihan diskrit dinyatakan sebagai peluang setiap individu memilih suatu pilihan merupakan fungsi ciri sosioekonomi dan daya tarik pilihan tersebut. Untuk menyatakan daya tarik suatu alternatif, digunakan konsep utilitas dan didefinisikan sebagai sesuatu yang dimaksimumkan oleh setiap individu. Domencich and McFadden, 
1975 dan Williams, 1977, sebagaimana dikutip dari Tamin ${ }^{16)}$, mengemukakan bahwa setiap set pilihan utilitas Uin untuk setiap individu $n$. Pemodel yang juga merupakan pengamat sistem tersebut tidak mempunyai informasi yang lengkap tentang semua unsur yang dipertimbangkan oleh setiap individu yang menentukan pilihan. Sehingga dalam membuat model diasumsikan bahwa Uin dapat dinyatakan dalam dua komponen, yaitu

1. Vin yang terukur sebagai fungsi dari atribut terukur.

2. Bagian acak sin, yang mencerminkan hal tertentu dari setiap individu, termasuk kesalahan yang dilakukan oleh pemodel.

Secara umum, pengaruh tersebut dapatdiekspresikan menjadi :

$U_{\text {in }}=V_{\text {in }}+\varepsilon_{\text {in }}$

dengan :

$U_{\text {in }}=$ utilitas alternatif $i$ bagi pembuat keputusan $n$

$V_{\text {in }} \quad=$ fungsi deterministik utilitas moda $i$ bagi individu $n$

$\varepsilon_{\text {in }} \quad=$ kesalahan acak (random error) atau kompenen stokastik dan fungsi distribusi tertentu

Persamaan tersebut dapat menjelaskan hal-hal yang tidak rasional. Contohnya, dua individu dengan atribut yang sama dan mempunyai set pilihan yang sama mungkin memilih pilihan yang berbeda dan beberapa individu tidak selalu memilih alternatif yang terbaik. Agar persamaan tersebut benar, dibutuhkan populasi yang homogen. Individu yang berada dalam suatu populasi yang homogen akan bertindak secara rasional dan memiliki informasi yang tepat sehingga biasanya dapat menentukan pilihan yang dapat memaksimumkan utilitas individunya masing-masing sesuai dengan batasan hukum, sosial, fisik, waktu dan uang.

\section{Model Logit Binomial}

Pengambilan keputusan pada model logit binomial ditentukan pada sepasang alternatif diskrit, dimana alternatif yang akan dipilih adalah yang mempunyai utilitas terbesar, utilitas dalam hal ini dipandang sebagai utilitas acak (random utility). Pada penelitian ini akan disurvei kecenderungan penumpang dalam memilih moda antara kereta api (KA) ekspres (moda baru) dengan kereta api (KA) eksekutif saat ini dan antara KA ekspres (moda baru) dengan pesawat udara pada rute Jakarta - Semarang.
Dengan dua alternatif moda maka persamaan tersebut dapat ditulis sebagai berikut.

$$
\begin{gathered}
P_{M S T}=\frac{e x p^{U M S T}}{\exp ^{U M S T}+e x p^{\text {Uair }}} \\
P_{\text {air }}=1-P_{M S T}
\end{gathered}
$$

dengan:

$P_{M S T}:$ adalah probabilitas untuk memilih KA
Ekspres
$P_{\text {air }}: \begin{aligned} & \text { :adalah probabilitas untuk moda } \\ & \text { pesawat, }\end{aligned}$

\section{Pemilihan Moda dan Survei Lapangan}

Pelaku perjalanan umumnya menentukan pilihan moda yang akan digunakan dengan melihat utilitas suatu moda yang paling baik. Utilitas moda dalam penelitian ini terdiri dari variabel waktu dan biaya perjalanan. Utilitas suatu moda tertinggi jika memiliki waktu pelayanan dan biaya perjalanan terendah.

Jou et al. ${ }^{17)}$ mensimulasikan inisiasi layanan transportasi berkecepatan tinggi yang terikat ke Bandara Internasional Taoyuan (TIA) di Taiwan dan menganalisis pilihan penumpang internasional ketika berada di bawah pengaruh waktu tempuh di dalam kendaraan, waktu tempuh di luar kendaraan dan biaya bahan bakar.

Jung dan Yoo ${ }^{18}$ ) berhipotesis bahwa versi yang lebih cepat dari layanan Korea Train Express (KTX) akan menghubungkan Gimpo (Seoul) dan Gimhae (Busan), dan menganalisis perilaku pilihan mode penumpang bisnis dan rekreasi di antara Full Service Carrier (FSC), Rendah Cost Carrier (LCC) dan KTX melalui studi perbandingan menggunakan model Multinomial Logit (MNL) dan Nested Logit (NL). Tarif, waktu akses, waktu perjalanan, dan frekuensi dianggap sebagai variabel. Hasilnya menunjukkan bahwa penumpang umumnya memberi bobot pada pengurangan waktu akses dalam memilih moda transportasi.

Beberapa studi tentang masalah apakah penyediaan dan permintaan layanan udara dipengaruhi oleh HSR telah dilakukan. Misalnya, Dobruszkes et al. ${ }^{19)}$, melakukan analisis ex-post untuk menemukan bahwa waktu tempuh HSR yang lebih pendek melibatkan lebih sedikit layanan udara di Eropa, dengan dampak yang sama pada kursi dan penerbangan maskapai.

Pada penelitian ini, dalam membentuk model, parameter utilitas yang digunakan adalah beda waktu perjalanan (TD) dan beda biaya perjalanan (CD). 
Oleh karena itu, dalam survei Stated Preference, dilakukan wawancara kepada calon penumpang di bandara dan stasiun kereta api dengan memberikan beberapa pertanyaan yang menggambarkan variasi kondisi alternatif pelayanan atas pemilihan moda yang ditawarkan.

Pemilihan responden pada studi ini mengacu pada metode stratified random sampling, yaitu proses pengambilan sampel melalui proses pembagian populasi ke dalam strata (lokasi asal dan tujuan), memilih sampel acak sederhana dari setiap stratum dan menggabungkannya ke dalam sebuah sampel untuk menaksir parameter populasinya.

Pada dasarnya tidak ada satu rumus pun yang dapat menentukan ukuran sampel secara paling tepat dan tidak ada pula aturan yang dapat menjelaskan dengan tegas antara sampel besar dan sampel kecil20). Pada studi ini digunakan acuan metode Roscoe ${ }^{21)}$ dalam menentukan jumlah sampel. Menurut Roscoe ${ }^{21)}$, untuk kebanyakan penelitian ukuran sampel lebih dari 30 dan kurang dari 500 adalah cukup.

Tabel 1.

Jumlah Responden Rute Jakarta - Semarang

\begin{tabular}{|c|c|c|c|}
\hline \multirow[b]{2}{*}{ Rute } & \multirow[b]{2}{*}{ Lokasi } & \multicolumn{2}{|c|}{ Survei SP } \\
\hline & & $\begin{array}{c}\text { Jumlah } \\
\text { Responden }\end{array}$ & $\begin{array}{c}\text { Rasio } \\
\text { Sampel }\end{array}$ \\
\hline \multirow{2}{*}{$\begin{array}{l}\text { JKT - } \\
\text { SMG }\end{array}$} & $\begin{array}{c}\text { Bandar } \\
\text { udara }\end{array}$ & 1317 & $3 \%$ \\
\hline & Stasiun & 193 & $2 \%$ \\
\hline
\end{tabular}

Namun pada praktiknya, besarnya target sampel memerlukan beberapa penyesuaian tergantung kondisi lapangan dan kompleksitas dari masing-masing lokasi survei. Dalam pelaksanaannya akan terdapat keragaman jumlah sampel yang berhasil dikumpulkan. Jumlah responden dan lokasi survei ditunjukkan pada Tabel 1.

Tabel 2.

Format Pilihan Untuk

Penumpang Pesawat Udara

\begin{tabular}{|c|c|c|c|c|c|c|}
\hline \multicolumn{2}{|c|}{$\begin{array}{l}\text { Naik Kereta } \\
\text { Api Ekspres }\end{array}$} & \multicolumn{5}{|c|}{$\begin{array}{l}\text { Pilihan Responden } \\
\quad(\text { beri tanda } \mathrm{x})\end{array}$} \\
\hline $\begin{array}{l}\text { Beda } \\
\text { Waktu }\end{array}$ & $\begin{array}{l}\text { Beda } \\
\text { Biaya }\end{array}$ & 1 & 2 & 3 & 4 & 5 \\
\hline (menit) & (Rp) & $\begin{array}{l}\text { Pes- } \\
\text { awat }\end{array}$ & $\begin{array}{l}\text { Pes- } \\
\text { awat }\end{array}$ & & $\begin{array}{c}\text { KA } \\
\text { eks } \\
\text { pres }\end{array}$ & $\begin{array}{l}\text { KA } \\
\text { eks } \\
\text { pres }\end{array}$ \\
\hline
\end{tabular}

Keterangan :

1.Tetap 2. Cenderung tetap 3. Netral

4. Cenderung naik 5. Naik
Dalam wawancara, responden diminta memilih kecenderungannya dalam menggunakan suatu moda, apakah tetap menggunakan moda saat ini atau ganti moda baru (kereta api ekspres). Adapun format pilihan untuk responden dari penumpang pesawat udara di bandara ditunjukkan pada Tabel 2.

Penumpang pesawat udara diberi pertanyaan untuk menentukan kecenderungan dalam memilih moda dalam beberapa variasi kondisi, jika naik KA ekspres waktu tempuh sama atau lebih cepat dan biaya sama atau lebih mahal dibandingkan dengan naik pesawat udara. Sedangkan untuk responden penumpang kereta api eksekutif di stasiun kereta api,pilihan jawaban kecenderungan pemilihan moda ditampilkan pada Tabel 3.

Tabel 3.

Format Pilihan Untuk Penumpang KA Eksekutif

\begin{tabular}{ccccccc}
\multicolumn{2}{c}{$\begin{array}{c}\text { Naik Kereta } \\
\text { Api Ekspres }\end{array}$} & \multicolumn{5}{c}{$\begin{array}{c}\text { Pilihan Responden } \\
\text { (beri tanda } \mathrm{x} \text { ) }\end{array}$} \\
$\begin{array}{c}\text { Beda } \\
\text { Waktu }\end{array}$ & $\begin{array}{c}\text { Beda } \\
\text { Biaya }\end{array}$ & 1 & 2 & 3 & 4 & 5 \\
(menit) & (Rp) & $\begin{array}{c}\text { KA } \\
\text { saat } \\
\text { ini }\end{array}$ & $\begin{array}{c}\text { KA } \\
\text { saat } \\
\text { ini }\end{array}$ & $\begin{array}{c}\text { KA } \\
\text { eks } \\
\text { pres }\end{array}$ & $\begin{array}{c}\text { KA } \\
\text { eks }\end{array}$ \\
& & & & & &
\end{tabular}

\section{Keterangan : \\ 1.Tetap 2. Cenderung tetap 3. Netral 4. Cenderung naik 5. Naik}

Penumpang KA Eksekutif diberi pertanyaanuntuk menentukan kecenderungan dalam memilih moda dalam beberapa variasi kondisi, jika naik KA ekspres waktu tempuh sama atau lebih cepat dan biaya sama atau lebih mahal dibandingkan dengan naik KA Eksekutif.

Fungsi utilitas dibangun dengan menghitung pengaruh komponen atribut yang berhubungan dengan pilihan moda menggunakan regresi linear. Utilitas pada dua model kompetisi, pertama, pesawat udara dengan KA ekspres dan kedua KA eksekutif dengan KA ekspres. Kedua model tersebut adalah sebagai berikut:

Model 1 (Pesawat udara dengan KA ekspres)

$U_{m s t}-U_{\text {air }}=\beta_{0}+\beta_{1}\left(T_{m s t}-T_{\text {air }}\right)+$ $\beta_{2}\left(C_{m s t}-C_{\text {air }}\right)$ 
Model 2 (KA eksekutif dengan KA ekspres)

$$
\begin{aligned}
& U_{m s t}-U_{k a}=\beta_{0}+\beta_{1}\left(T_{m s t}-T_{k a}\right)+\beta_{2}\left(C_{m s t}-\right. \\
& \left.C_{k a}\right)
\end{aligned}
$$

Untuk menghitung probabilitas preferensi KA ekpres $\left(P_{m s t}\right)$ dibandingkan dengan pesawat udara digunakan persamaan berikut.

$$
P_{m s t}=\frac{\exp (\text { Umst-Uair })}{1+\exp (\text { Umst-Uair })}
$$

Sedangkan untuk menghitung probabilitas preferensi KA ekpres $\left(P_{m s t}\right)$ dibandingkan dengan KA eksekutif digunakan persamaan berikut.

$$
P_{m s t}=\frac{\exp (U m s t-U k a)}{1+\exp (U m s t-U k a)}
$$

\section{HASIL DAN PEMBAHASAN}

Kondisi saat ini menunjukkan bahwa harga tiket pesawat udara relatif lebih mahal dibandingkan harga tiket kereta api. Tabel 4 menunjukkan komparasi waktu tempuh dan harga tiket.

Tabel 4.

Waktu Tempuh dan Harga Tiket Rute Jakarta - Semarang

\begin{tabular}{lcc}
\hline Keretangan & $\begin{array}{c}\text { Pesawat } \\
\text { Udara } \\
\text { JKT-SMG }\end{array}$ & $\begin{array}{c}\text { Kereta Api } \\
\text { JKT-SMG }\end{array}$ \\
\hline $\begin{array}{l}\text { Waktu Tempuh } \\
\text { Rata-Rata (jam) }\end{array}$ & $\begin{array}{l}\text { 4,3 (total) } \\
\begin{array}{l}\text { Harga Tiket } \\
\text { Rata-Rata }\end{array}\end{array}$ & $\begin{array}{c}\text { (hanya on } \\
\text { board) }\end{array}$ \\
\hline
\end{tabular}

Kalibrasi adalah proses estimasi nilai parameter dalam persamaan yang memberikan hasil terbaik atau terdekat dengan pengamatan di lapangan. Analisis dalam persamaan regresi akan menghasilkan nilai numerik konstanta dan koefisien regresi persamaan. Hasil perhitungan regresi untuk fungsi utilitas dapat dilihat pada Tabel 5 .
Dari analisis regresi pada Tabel 5 dengan confidence level 95\% diperoleh bahwa $R^{2}$ model utilitas pada penumpang pesawat udara adalah sebesar 0.51 dan penumpang kereta api 0.56. Berarti kedekatan antara model dengan keadaan lapangan relatif masih baik. Ini berarti bahwa pengaruh semua atribut terhadap perubahan utilitas pada model ini adalah $51 \%$ dan $56 \%$ sisanya dipengaruhi oleh atribut lain yang tidak dipertimbangkan dalam model ini.

Pada fungsi utilitas tersebut, variabel waktu perjalanan memiliki tanda positif $(+)$ pada semua persamaan baik dengan pesawat udara maupun KA eksekutif. Ini berarti bahwa jika perjalanan dengan KA ekspres lebih cepat akan menaikkan utilitas kereta api ekspres, sehingga probabilitas penumpang beralih ke kereta api ekspres meningkat.

Sedangkan variabel biaya perjalanan memiliki tanda negatif (-), ini berarti bahwa jika biaya perjalanan dengan KA ekspres meningkat akan menurunkan utilitas $\mathrm{KA}$ ekspres, sehingga probabilitas penumpang beralih ke KA ekspres akan menurun juga. Gambar 1 dan Gambar 2 berturut-turut menunjukkan probabilitas pemilihan moda pada responden penumpang pesawat udara

\begin{tabular}{|c|c|c|}
\hline Variable & Aircraft & $\begin{array}{c}\text { Executive } \\
\text { Train }\end{array}$ \\
\hline \multicolumn{3}{|l|}{ Constants } \\
\hline$\square 0$ & -0.664179 & 2.939257 \\
\hline t-stat & -5.183419 & 11.401470 \\
\hline $\begin{array}{l}\text { Independen } \\
\text { Time } \\
\text { Different } \\
\text { (口1) }\end{array}$ & 0.127809 & 3.790528 \\
\hline $\begin{array}{l}\text { Cost } \\
\text { Diffrent } \\
\text { ( } \square 2)\end{array}$ & 30.467758 & 27.131992 \\
\hline t-stat & -34.400963 & -53.820096 \\
\hline Multiple $\mathrm{R}^{2}$ & 0.716458 & 0.746943 \\
\hline $\mathrm{R}^{2}$ & 0.513313 & 0.557924 \\
\hline
\end{tabular}
dan kereta api kelas eksekutif

Tabel 5.

Hasil Analisis Regresi 


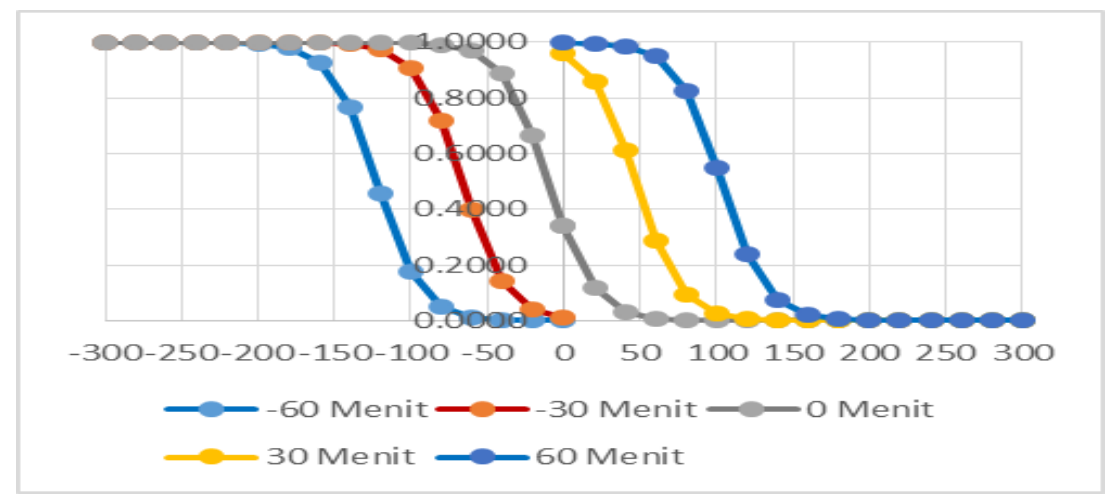

Gambar 1.

Probabilitas Pemilihan Moda Penumpang Pesawat Udara

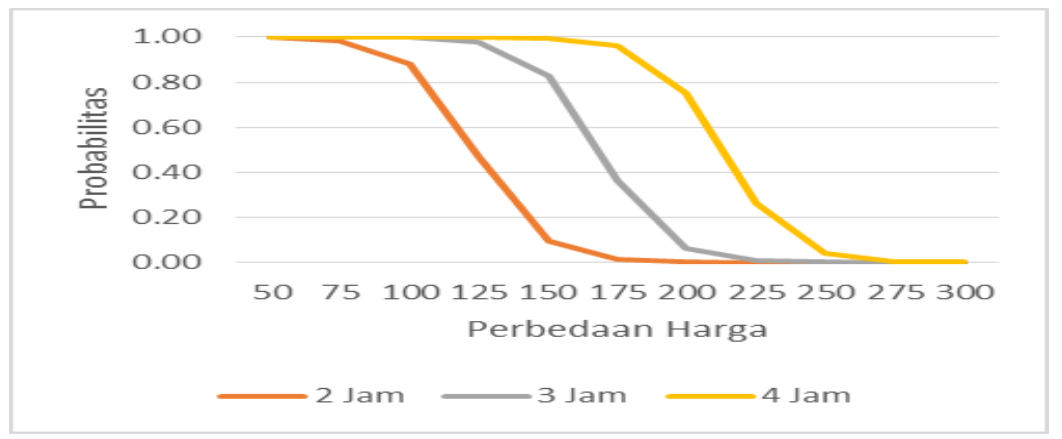

Gambar 2.

Probabilitas Pemilihan Moda Penumpang Kereta Api Ekeskutif

Dari Gambar 1, menjelaskan bahwa probabilitas pemilihan moda untuk penumpang pesawat udara dengan kereta api ekspres terlihat apabila waktu tempuh dan biaya perjalanan sama maka probabilitas penumpang pesawat udara yang akan berpindah menggunakan kereta api ekspres sekitar 34\%. Sedangkan, Gambar 2, penumpang kereta api kelas eksekutif dengan kereta api ekspres seandainya tiket kereta api ekspres lebih mahal Rp. 151.000,(menjadi Rp. 475.000,-) dan waktu tempuh lebih cepat 2,5 jam (menjadi 3,5 jam) maka penumpang kereta api eksekutif yang akan berpindah sekitar 40\%. Sedangkan penumpang pesawat udara pada kondisi yang sama, jika tiket KA ekspres Rp 475.000,- (lebih murah Rp. 45.000,-) dan waktu tempuh total (termasuk waktu akses) menjadi sekitar 5 jam (lebih lambat sekitar 46 menit) maka penumpang pesawat yang akan berpindah ke KA ekspres sekitar $2,7 \%$.

Dari hasil simulasi menunjukkan bahwa penumpang pesawat udara lebih sensitif terhadap perubahan waktu tempuh dibandingkan penumpang KA eksekutif. Dari persamaan yang ada juga menunjukkan bahwa penumpang pesawat udara memiliki kemampuan membeli yang lebih tinggi dibandingkan penumpang KA eksekutif.
Jika waktu perjalanan KA ekspres 2,8 jam (kecepatan rata-rata $155,5 \mathrm{~km} / \mathrm{jam}$ ), maka potensi pendapatan terbesar jika tarif Rp. 360.000,-/penumpang. Pada kondisi ini KA ekspres waktu perjalanannya sama dengan pesawat udara (waktu access dan egress sekitar 1,5 jam) dan lebih cepat 3,2 jam dibandingkan KA eksekutif. Jumlah penumpang pesawat udara mencapai 2,85 juta penumpang/tahun dan kereta api eksekutif 0,62 juta penumpang/tahun.

\section{SIMPULAN}

Berdasarkan hasil analisis dan pembahasan yang telah dilakukan pada penelitian ini dapat diambil kesimpulan beberapa hal sebagai berikut hasil analisis regresi untuk model utility pemilihan moda antara pesawat udara dengan KA ekspres dan antara KA eksekutif dengan KA ekspres rute Jakarta-Semarang berturut-turut memiliki nilai $R^{2}$ sebesar $51,33 \%$ dan $55,79 \%$. Ini menunjukkan bahwa model tersebut masih cukup bagus untuk digunakan, penumpang pesawat udara lebih sensitif terhadap perubahan waktu tempuh dibandingkan penumpang KA eksekutif, penumpang pesawat udara memiliki kemampuan membeli yang lebih tinggi dibandingkan penumpang 
KA eksekutif, dengan beroperasinya kereta ekpres Jakarta-Semarang dapat diindikasikan akan adanya perpindahan penumpang baik dari penumpang pesawat udara maupun kereta api kelas eksekutif.

\section{SARAN}

Untuk mendapatkan harga tiket yang optimum, selain besarnya permintaan penumpang yang memberikan pendapatan terbesar, perlu dilakukan penelitian lebih lanjut dengan memasukkan biaya operasi dan perawatan kereta api.

\section{UCAPAN TERIMA KASIH}

Ucapan terima kasih kami sampaikan kepada Kementerian Perhubungan, Direktorat Jenderal Perkeretaapian, dan Pusat Pelayanan Teknologi BPPT, yang telah mendukung terlaksananya kegiatan penelitian ini.

\section{DAFTAR PUSTAKA}

1. Kementerian Perhubungan dan BPPT, Pra Studi Kelayakan Peningkatan Kecepatan Kereta Api Koridor Jakarta Surabaya, 2017

2. Ortuzar, J.D., and Willumsen, L.G., Modelling Transport $3^{\text {rd }}$ edition, John Wiley and Sons Ltd, England. 2001

3. Chang, L., Sun, P., Stated-choice analysis of willingness to pay for low cost carrier services. J. Air Transp. Manag. 20, 15e17, 2012

4. Yulai Wan, Hun-Koo $\mathrm{Ha}$, Yuichiro Yoshida, Anming Zhang, Airlines' reaction to high-speed rail entries: Empirical study of the Northeast Asian market, Transportation Research Part A 94, 532557, 2016

5. Jiang, C., Zhang, A., Effects of highspeed rail and airline cooperation under hub airport capacity constraint. Transport. Res. Part B: Methodol. 60, 33-49. 2014

6. Albalate, D., Bel, G., Fageda, X.. Competition and cooperation between high-speed rail and air transportation services in Europe. J. Transp. Geogr. 42, 166-174. 2015

7. Xia, W., Zhang, A., High-Speed Rail and Air Transport Competition and Cooperation: A Vertical Integration Approach. Working Paper, Sauder School of Business, University of British Columbia. 2016a

8. Xia, W., Zhang, A., Effects of Air and High-Speed Rail Transport Integration on Profits and Welfare: The Case of Air-Rail Connecting Time. Working Paper, Sauder
School of Business, University of British Columbia. 2016b.

9. Castillo-Manzano, J.I., Pozo-Barajas, R., Trapero, J.R., Measuring the substitution effects between high speed rail and air transport in Spain. J. Transp. Geogr. 43, 59-65. 2015.

10. Armstrong, J., Preston, J., Alternative railway futures: growth and/or specialisation? J. Transp. Geogr. 19 (6), 1570-1579. 2011.

11. Bilotkach, V., Fageda, X., Flores-Fillol, R., Scheduled service versus personal transportation: the role of distance. Reg. Sci. Urban Econ. 40 (1), 60-72. 2010.

12. Jiménez, J.L., Betancor, O., When trains go faster than planes: the strategic reaction of airlines in Spain. Transp. Policy 23, 34-41. 2012.

13. Pearmain, D et al. Stated Preference Techniques: A Guide To Practice. Second edition, Steer Davies Gleave and Hague Consulting Group. 1991.

14. David Levinson, Henry Liu, William Garrison, Adam Danczyk, Michael Corbett, Fundamentals of Transportation, http://code.pediapress.com/, 2009

15. Nachrowi, N. Djalal dan Hardius Usman. Pendekatan Populer dan Praktis Ekonometrika untuk Analisis Ekonomi dan Keuangan, Jakarta: LPFE Universitas Indonesia. 2006

16. Tamin, Ofyar Z. Perencanaan dan Permodelan Transportasi. Bandung, Indonesia: Penerbit ITB. 2008.

17. Jou, R.-C., Hensher, D.A., Hsu, T.-L., Airport ground access mode choicebehavior after the introduction of a new mode: a case study of Taoyuan InternationalAirport in Taiwan. Transp. Res. Part E 47, 371e381, 2011.

18. Jung, S.-Y., Yoo, K.-E., Passenger airline choice behavior for domestic shorthaultravel in South Korea. J. Air Transp. Manag. 38, 43e47, 2014.

19. Dobruszkes, F., Dehon, C., Givoni, M., Does European high-speed rail affect the current level of air services? an EU-wide analysis. Transp. Res. Part A: Policy Pract. 69, 461e475, 2014

20. Arsyad, Lincolin, Soeratno, Metodologi Penelitian Untuk Ekonomi dan Bisnis, UPPAMP YKPN, Yogyakarta, 1995.

21. Roscoe, J.T., Fundamental Research tatistics for The Behavioural Sciences, $2^{\text {nd }}$ edition, New York: Holt Rinehart and Winston, 1975. 